\title{
Laryngeal Cancer pNX TNM Finding v8
}

National Cancer Institute

\section{Source}

National Cancer Institute. Laryngeal Cancer pNX TNM Finding v8. NCI Thesaurus. Code C133140.

Laryngeal cancer in which the regional lymph nodes cannot be assessed. (from AJCC 8th Ed.) 